\title{
One-pot preparation of 4-aryl-3-bromocoumarins from 4-aryl-2-propynoic acids with diaryliodonium salts, TBAB, and $\mathrm{Na}_{2} \mathrm{~S}_{2} \mathrm{O}_{8}$
}

\author{
Teppei Sasaki ${ }^{1}$, Katsuhiko Moriyama ${ }^{1,2}$ and Hideo Togo ${ }^{* 1}$
}

\author{
Full Research Paper \\ Address: \\ ${ }^{1}$ Department of Chemistry, Graduate School of Science, Chiba \\ University, Yayoi-cho 1-33, Inage-ku, Chiba 263-8522, Japan and \\ ${ }^{2}$ Molecular Chirality Research Center, Chiba University, Yayoi-cho \\ 1-33, Inage-ku, Chiba 263-8522, Japan \\ Email: \\ Hideo Togo* - togo@faculty.chiba-u.jp \\ * Corresponding author \\ Keywords: \\ 3-aryl-2-propynoic acid; bromo-cyclization; coumarin; diaryliodonium \\ triflate; O-phenylation
}

Beilstein J. Org. Chem. 2018, 14, 345-353. doi:10.3762/bjoc. 14.22

Received: 11 December 2017

Accepted: 26 January 2018

Published: 05 February 2018

This article is part of the Thematic Series "Hypervalent iodine chemistry in organic synthesis".

Guest Editor: T. Wirth

(C) 2018 Sasaki et al.; licensee Beilstein-Institut. License and terms: see end of document.

\begin{abstract}
Various 4-aryl-3-bromocoumarins were smoothly obtained in moderate yields in one pot by treating 3-aryl-2-propynoic acids with diaryliodonium triflates and $\mathrm{K}_{2} \mathrm{CO}_{3}$ in the presence of $\mathrm{CuCl}$, followed by the reaction with tetrabutylammonium bromide (TBAB) and $\mathrm{Na}_{2} \mathrm{~S}_{2} \mathrm{O}_{8}$. The obtained 3-bromo-4-phenylcoumarin was transformed into 4-phenylcoumarin derivatives bearing $\mathrm{C}-\mathrm{H}, \mathrm{C}-\mathrm{S}$, $\mathrm{C}-\mathrm{N}$, and $\mathrm{C}-\mathrm{C}$ bonds at 3-position.
\end{abstract}

\section{Introduction}

Coumarin is a benzo- $\alpha$-pyrone and one of the typical heterocyclic compounds. The importance of coumarins arises from the fact that the coumarin skeleton is present in many natural products extracted from plants [1-3] and some of them show potent pharmacological activities, such as antidepressant [4], antimicrobial $[5,6]$, antioxidants $[7,8]$, anti-inflammatory $[9,10]$, antinociceptive [11], antitumor [1], antiasthmatic [12], and antiviral including anti-HIV $[13,14]$.
Comprehensive synthetic studies of coumarins and their derivatives have been carried out $[15,16]$. Typically, coumarins are prepared by the acid-catalyzed condensation of 2-alkynoic acids and phenols or the condensation of $\beta$-ketoesters and phenols (the Pechmann condensation) [17]. Recent studies for the metalcatalyzed reactions for the synthesis of the coumarin skeleton are as follows: the $\mathrm{Yb}(\mathrm{OTf})_{3}$-catalyzed microwave irradiation of phenols and propynoic acids [18], the $\mathrm{Pd}(\mathrm{OAc})_{2}$-catalyzed 
oxidative cyclocarbonylation of 2-vinylphenols at $110^{\circ} \mathrm{C}[19]$, the $\mathrm{FeCl}_{3}$-catalyzed areneselenyl-cyclization of aryl 2-alkynoates with ArSeSeAr at rt [20], and the Rh-catalyzed annulation of arylthiocarbamates with alkynes/AgOTf $/ \mathrm{Cu}(\mathrm{OAc})_{2}$ at $120{ }^{\circ} \mathrm{C}$ [21]. As examples of the transition-metal-free construction of the coumarin skeleton, the Brønsted acid-catalyzed reaction of phenols and propynoic acids [22] and the (-)-riboflavincatalyzed photochemical reaction of cinnamic acids [23] were reported recently. Moreover, the use of radical cyclization for the construction of the coumarin skeleton has become widespread. Examples include the radical addition-cyclization reactions of aryl 2-alkynoates with $\mathrm{RC}(=\mathrm{O}) \mathrm{CO}_{2} \mathrm{H} / \mathrm{AgNO}_{3}$ (cat.)/ $\mathrm{K}_{2} \mathrm{~S}_{2} \mathrm{O}_{8}$ at $60{ }^{\circ} \mathrm{C}$ [24], with $\mathrm{Cu}(\mathrm{OAc})_{2} / 1$-trifluoromethyl-3,3dimethyl-1,2-benziodoxole (Togni reagent) at $60{ }^{\circ} \mathrm{C}$ [25], with $\mathrm{R}_{2} \mathrm{P}(=\mathrm{O}) \mathrm{H} / \mathrm{Ag}_{2} \mathrm{CO}_{3}$ (cat.) $/ \mathrm{Mg}\left(\mathrm{NO}_{3}\right)_{2}$ at $100{ }^{\circ} \mathrm{C}$ [26], with $\mathrm{BrCF}_{2} \mathrm{CO}_{2} \mathrm{Et} / f a c-\operatorname{Ir}(\mathrm{ppy})_{3}$ (cat.) under irradiation at $\mathrm{rt}$ [27], with $\mathrm{R}-\mathrm{CH}=\mathrm{O} /(n-\mathrm{Bu})_{4} \mathrm{NBr}(\mathrm{TBAB}$, cat. $) / \mathrm{K}_{2} \mathrm{~S}_{2} \mathrm{O}_{8}$ at $90{ }^{\circ} \mathrm{C}$ [28], with $\mathrm{ArSO}_{2} \mathrm{H} /$ Eosin $\mathrm{Y}$ (cat.)/tert-butyl hydrogen peroxide (TBHP) at rt [29], and with $\mathrm{ArSO}_{2} \mathrm{NHNH}_{2} / n-\mathrm{Bu}_{4} \mathrm{NI}$ (cat.)/TBHP at $80{ }^{\circ} \mathrm{C}$ [30].

In addition, the formation of coumarins via the bromine-radicalmediated reaction of aryl 2-alkynoates with $\mathrm{TBAB} / \mathrm{K}_{2} \mathrm{~S}_{2} \mathrm{O}_{8}$ at $90{ }^{\circ} \mathrm{C}[31]$, the cyanomethyl-radical-mediated reaction of aryl 2-alkynoates with tert-butyl peroxybenzoate (TBPB)/acetonitrile at $130{ }^{\circ} \mathrm{C}[32]$, the sunlight-promoted reaction of aryl 2-alkynoates with $N$-iodosuccinimide (NIS) at rt [33], and the visible-light-mediated reaction of aryl 2-alkynoates with $\mathrm{N}$-bromosuccinimide (NBS) at rt [34], where those reactions proceed via radical spiro-cyclization and then radical 1,2carboxyl group migration, were reported.

On the other hand, diaryliodonium salts are very useful for the $\mathrm{C}$-arylation of active $\mathrm{CH}$ groups, the $\mathrm{O}$-arylation of $\mathrm{OH}$ groups, and the $\mathrm{N}$-arylation of $\mathrm{NH}$ groups under metal-free conditions [35-39]. For example, treatment of arenecarboxylic acids and alkanecarboxylic acids with diaryliodonium salts and $t$-BuOK under toluene refluxing conditions provides the corresponding aryl carboxylates in good yields [40,41]. However, the O-arylation of 2-alkynoic acids, which are much more acidic than arenecarboxylic acids and alkanecarboxylic acids, and therefore, the conjugate bases of 2-alkynoic acids are much less nucleophilic than those of arenecarboxylic acids and alkanecarboxylic acids, was not studied. On the other hand, it is known that 4-arylcoumarins have antitumor activity [42]. Therefore, the one-pot preparation of 4-arylcoumarins from 3-aryl-2alkynoic acids via aryl esters and cyclization is attractive and important.

Here, as part of our ongoing investigation of the synthetic use of diaryliodonium salts for the preparation of heterocyclic com- pounds [43-46], we would like to report an efficient one-pot preparation of 4-aryl-3-bromocoumarins by treatment of 3-aryl2-propynoic acids with diaryliodonium triflate in the presence of a base, followed by the reaction with tetrabutylammonium bromide (TBAB) and $\mathrm{Na}_{2} \mathrm{~S}_{2} \mathrm{O}_{8}$ in a mixture of 1,2-dichloroethane and water [31].

\section{Results and Discussion}

First, treatment of 3-phenyl-2-propynoic acid (1a, $0.5 \mathrm{mmol}$ ) with diphenyliodonium triflate (A, 1.0 equiv) in the presence of $\mathrm{CuCl}(5 \mathrm{~mol} \%)$ and $\mathrm{K}_{2} \mathrm{CO}_{3}$ (1.0 equiv) in dichloromethane $(3.0 \mathrm{~mL})$ at $40{ }^{\circ} \mathrm{C}$ based on a previous report [46] gave phenyl 3 -phenyl-2-propynoate (2Aa) in $46 \%$ yield, as shown in Table 1, entry 1 . When the amount of the solvent was increased to $7.5 \mathrm{~mL}$ under the same conditions, the yield of phenyl ester 2Aa was increased to $74 \%$ (Table 1, entry 2). Under the same conditions, the base was changed to $\mathrm{NaH}, \mathrm{Cs}_{2} \mathrm{CO}_{3}, t$-BuOK, $\mathrm{NaNH}_{2}$, and $\mathrm{K}_{3} \mathrm{PO}_{4}$ instead of $\mathrm{K}_{2} \mathrm{CO}_{3}$. However, the yield of phenyl ester 2Aa was moderate to low (Table 1, entries 3-7). When the amount of $\mathrm{K}_{2} \mathrm{CO}_{3}$ was reduced to 0.5 equiv under the same conditions as those in entry 2 , the yield of phenyl ester 2Aa was increased to $80 \%$ (Table 1, entry 8). When $\mathrm{CuCl}$ was changed to $\mathrm{CuI}$ and $\mathrm{CuBr}$, the difference of the yield of phenyl ester $\mathbf{2 A a}$ was small, but $\mathrm{CuCl}$ gave the highest yield (Table 1, entries $8-10)$. Then, the reaction temperature was changed to $0{ }^{\circ} \mathrm{C}$, rt, $50{ }^{\circ} \mathrm{C}$, and $60{ }^{\circ} \mathrm{C}$ under the same conditions as those in entry 8 , and phenyl ester $\mathbf{2 A a}$ was obtained in $83 \%$ yield at $50{ }^{\circ} \mathrm{C}$ (Table 1, entries 11-14). On the other hand, when the present reaction was carried out without $\mathrm{CuCl}$ under the same conditions, phenyl ester 2Aa was not obtained at all (Table 1, entry 15$)$.

Then, the iodocyclization of phenyl ester 2Aa to 3-iodo-4phenylcoumarin (3Aa') with $\mathrm{N}$-iodosuccinimide (NIS, 2.0 equiv) $/ \mathrm{BF}_{3} \cdot \mathrm{Et}_{2} \mathrm{O}$ ( 2.0 or 1.1 equiv) was studied based on the previous reports $[45,46]$, as shown in Table 2. However, 3 -iodo4-phenylcoumarin (3Aa') was obtained in low to moderate yields (Table 2, entries 1 and 2). To improve the yield of 3-halo-4-phenylcoumarins 3Aa or 3Aa', the halocyclization of 2Aa with $N$-bromosuccinimide (NBS, 2.0 equiv) $/ \mathrm{BF}_{3} \cdot \mathrm{Et}_{2} \mathrm{O}$ (1.1 equiv), with 1,3-diiodo-5,5-dimethylhydantoin (DIH, 2.0 equiv) $/ \mathrm{BF}_{3} \cdot \mathrm{Et}_{2} \mathrm{O}$ (1.1 equiv), and with 1,3-dibromo-5,5dimethylhydantoin ( $\mathrm{DBH}, 2.0$ equiv) $/ \mathrm{BF}_{3} \cdot \mathrm{Et}_{2} \mathrm{O}$ (1.1 equiv) was carried out to form 3-bromo-4-phenylcoumarin (3Aa), 3-iodo4-phenylcoumarin (3Aa'), and 3-bromo-4-phenylcoumarin (3Aa) in 28, 49 and 46\% yields, respectively (Table 2, entries 3-5). The treatment of phenyl ester $2 \mathrm{Aa}$ with molecular iodine (2.0 equiv) $/ \mathrm{K}_{2} \mathrm{CO}_{3}$ (2.0 equiv) did not generate 3 -iodo-4phenylcoumarin (3Aa') at all (Table 2, entry 6). Thus, the iodonium-based or bromonium-based electrophilic cyclization of phenyl 3-phenyl-2-propynoate (2Aa) does not proceed effi- 
Table 1: O-Phenylation of 3-phenyl-2-propynoic acid (1a) with diphenyliodonium triflate (A).

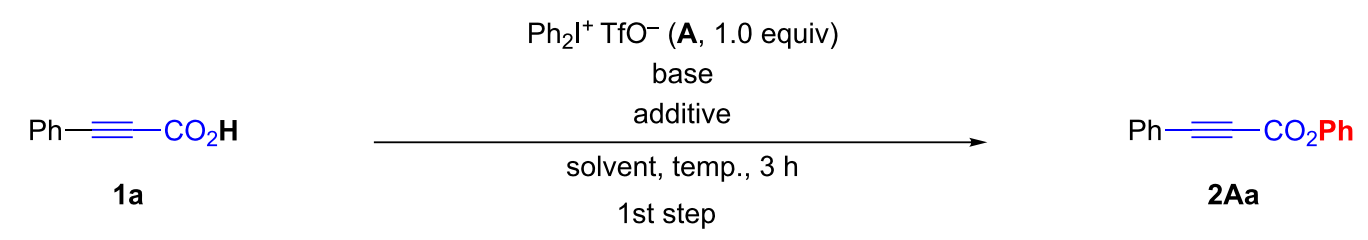

\begin{tabular}{|c|c|c|c|c|c|}
\hline entry & base & solvent (mL) & additive (mol \%) & temp. $\left({ }^{\circ} \mathrm{C}\right)$ & yield (\%) \\
\hline 1 & $\mathrm{~K}_{2} \mathrm{CO}_{3}(1.0)$ & $\mathrm{CH}_{2} \mathrm{Cl}_{2}(3.0)$ & $\mathrm{CuCl}(5)$ & 40 & 46 \\
\hline 2 & $\mathrm{~K}_{2} \mathrm{CO}_{3}(1.0)$ & $\mathrm{CH}_{2} \mathrm{Cl}_{2}(7.5)$ & $\mathrm{CuCl}(5)$ & 40 & 74 \\
\hline 3 & $\mathrm{NaH}(1.0)$ & $\mathrm{CH}_{2} \mathrm{Cl}_{2}(7.5)$ & $\mathrm{CuCl}(5)$ & 40 & 24 \\
\hline 4 & $\mathrm{Cs}_{2} \mathrm{CO}_{3}(0.5)$ & $\mathrm{CH}_{2} \mathrm{Cl}_{2}(7.5)$ & $\mathrm{CuCl}(5)$ & 40 & 17 \\
\hline 5 & $t$-BuOK (1.0) & $\mathrm{CH}_{2} \mathrm{Cl}_{2}(7.5)$ & $\mathrm{CuCl}(5)$ & 40 & 48 \\
\hline 6 & $\mathrm{NaNH}_{2}(1.0)$ & $\mathrm{CH}_{2} \mathrm{Cl}_{2}(7.5)$ & $\mathrm{CuCl}(5)$ & 40 & 9 \\
\hline 7 & $\mathrm{~K}_{3} \mathrm{PO}_{4}(1.0)$ & $\mathrm{CH}_{2} \mathrm{Cl}_{2}(7.5)$ & $\mathrm{CuCl}(5)$ & 40 & 30 \\
\hline 8 & $\mathrm{~K}_{2} \mathrm{CO}_{3}(0.5)$ & $\mathrm{CH}_{2} \mathrm{Cl}_{2}(7.5)$ & $\mathrm{CuCl}(5)$ & 40 & 80 \\
\hline 9 & $\mathrm{~K}_{2} \mathrm{CO}_{3}(0.5)$ & $\mathrm{CH}_{2} \mathrm{Cl}_{2}(7.5)$ & Cul (5) & 40 & 78 \\
\hline 10 & $\mathrm{~K}_{2} \mathrm{CO}_{3}(0.5)$ & $\mathrm{CH}_{2} \mathrm{Cl}_{2}(7.5)$ & CuBr (5) & 40 & 77 \\
\hline 11 & $\mathrm{~K}_{2} \mathrm{CO}_{3}(0.5)$ & $\mathrm{CH}_{2} \mathrm{Cl}_{2}(7.5)$ & $\mathrm{CuCl}(5)$ & 0 & 11 \\
\hline 12 & $\mathrm{~K}_{2} \mathrm{CO}_{3}(0.5)$ & $\mathrm{CH}_{2} \mathrm{Cl}_{2}(7.5)$ & $\mathrm{CuCl}(5)$ & $\mathrm{rt}$ & 71 \\
\hline 13 & $\mathrm{~K}_{2} \mathrm{CO}_{3}(0.5)$ & DCE (7.5) & $\mathrm{CuCl}(5)$ & 50 & 83 \\
\hline 14 & $\mathrm{~K}_{2} \mathrm{CO}_{3}(0.5)$ & DCE (7.5) & $\mathrm{CuCl}(5)$ & 60 & 75 \\
\hline 15 & $\mathrm{~K}_{2} \mathrm{CO}_{3}(0.5)$ & DCE (7.5) & - & 50 & 0 \\
\hline
\end{tabular}

Table 2: Halocyclization of phenyl 3-phenyl-2-propynoate (2Aa) to 3-halo-4-phenylcoumarins 3Aa and 3Aa'.

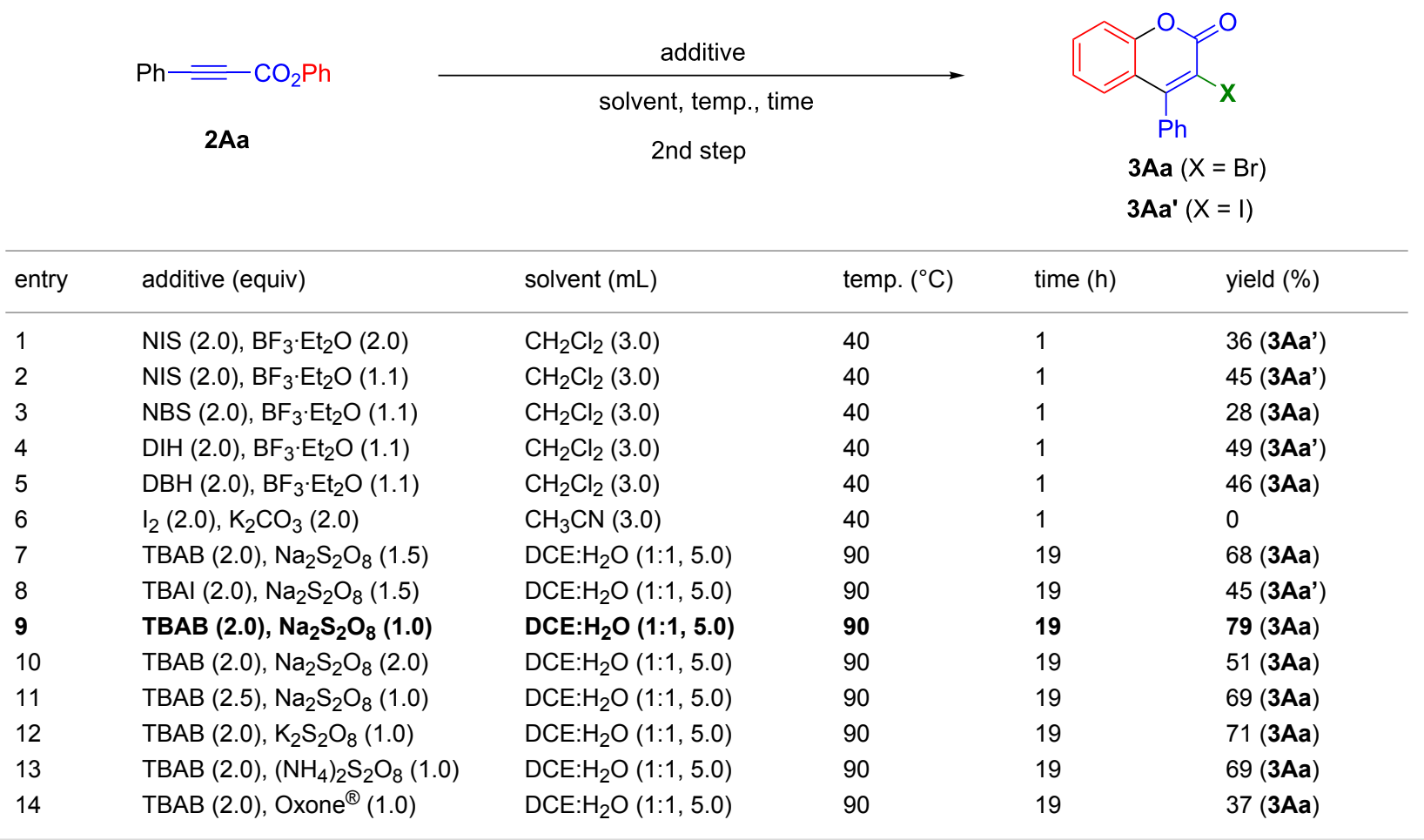


ciently. Then, the bromo-radical-based cyclization of phenyl 3-phenyl-2-propynoate (2Aa) with tetrabutylammonium bromide (TBAB, 2.0 equiv) $/ \mathrm{Na}_{2} \mathrm{~S}_{2} \mathrm{O}_{8}$ (1.5 equiv) [31] in a mixture of 1,2-dichloroethane (DCE) and water at $90{ }^{\circ} \mathrm{C}$ was carried out to give 3-bromo-4-phenylcoumarin (3Aa) in $68 \%$ yield (Table 2, entry 7). When the iodocyclization of phenyl ester 2Aa with tetrabutylammonium iodide (TBAI, 2.0 equiv)/ $\mathrm{Na}_{2} \mathrm{~S}_{2} \mathrm{O}_{8}$ (1.5 equiv) was carried out, the yield of iodocyclization product 3Aa' was decreased to $45 \%$ (Table 2, entry 8 ). When the bromocyclization of phenyl ester $2 \mathrm{Aa}$ with TBAB (2.0 equiv) $/ \mathrm{Na}_{2} \mathrm{~S}_{2} \mathrm{O}_{8}$ (1.0 equiv) in a mixture of DCE and water at $90{ }^{\circ} \mathrm{C}$ was carried out, 3-bromo-4-phenylcoumarin (3Aa) was obtained in $79 \%$ yield (Table 2 , entry 9 ). When $\mathrm{Na}_{2} \mathrm{~S}_{2} \mathrm{O}_{8}$ was increased to 2.0 equivalents or TBAB was increased to 2.5 equivalents under the same conditions, the yields of 3-bromo-4-phenylcoumarin (3Aa) were decreased to 51 and $69 \%$, respectively (Table 2, entries 10 and 11). Moreover, when $\mathrm{Na}_{2} \mathrm{~S}_{2} \mathrm{O}_{8}$ was changed to $\mathrm{K}_{2} \mathrm{~S}_{2} \mathrm{O}_{8},\left(\mathrm{NH}_{4}\right)_{2} \mathrm{~S}_{2} \mathrm{O}_{8}$, and Oxone ${ }^{\circledR}$ $\left(2 \mathrm{KHSO}_{5} \cdot \mathrm{KHSO}_{4} \cdot \mathrm{K}_{2} \mathrm{SO}_{4}\right)$, the yields of 3-bromo-4-phenylcoumarin (3Aa) were decreased to 71,69 and $37 \%$, respectively (Table 2, entries 12-14). Thus, it was confirmed that the treatment of phenyl ester $\mathbf{2 A a}$ with TBAB (2.0 equiv) $/ \mathrm{Na}_{2} \mathrm{~S}_{2} \mathrm{O}_{8}$ (1.0 equiv) in a mixture of DCE and water at $90{ }^{\circ} \mathrm{C}$ for $19 \mathrm{~h}$ was the most efficient, giving 3-bromo-4-phenylcoumarin (3Aa) in good yield (Table 2, entry 9).

Finally, based on the results in Table 1 and Table 2, the one-pot preparation of 4-aryl-3-bromocoumarins 3 from 3-aryl-2-propynoic acids 1 was carried out. 3-Aryl-2-propynoic acids $\mathbf{1}$, such as 3-phenyl-2-propynoic acid (1a), 3-(o-methylphenyl)-2propynoic acid (1b), 3-(m-methylphenyl)-2-propynoic acid (1c), 3 -( $p$-methylphenyl)-2-propynoic acid (1d), 3-( $p$-methoxyphenyl)-2-propynoic acid (1e), 3-( $p$-fluorophenyl)-2-propynoic acid (1f), 3-( $p$-chlorophenyl)-2-propynoic acid (1g), 3-(ochlorophenyl)-2-propynoic acid (1h), 3-(m-chlorophenyl)-2propynoic acid (1i), 3-( $p$-bromophenyl)-2-propynoic acid (1j), 3-( $p$-biphenyl)-2-propynoic acid (1k), 3-(naphthalen-2'-yl)-2propynoic acid (11), and 3-(naphthalen-1'-yl)-2-propynoic acid $(\mathbf{1 m})$, were treated with diphenyliodonium triflate (A, 1.0 equiv) in the presence of $\mathrm{CuCl}$ and $\mathrm{K}_{2} \mathrm{CO}_{3}$ in $\mathrm{CH}_{2} \mathrm{Cl}_{2}$ for $3 \mathrm{~h}$ under refluxing conditions. After removal of the solvent, the second-step treatment of the reaction mixture with TBAB (2.0 equiv) and $\mathrm{Na}_{2} \mathrm{~S}_{2} \mathrm{O}_{8}$ (2.0 equiv) in a mixture of DCE and water at $90{ }^{\circ} \mathrm{C}$ for $19 \mathrm{~h}$ gave 4 -aryl-3-bromocoumarins 3Aa-3Am in moderate yields, respectively, as shown in Scheme 1. As a gram-scale experiment, treatment of 3-phenyl2-propynoic acid (1a, $8 \mathrm{mmol}$ ) with diphenyliodonium triflate $A$ in the presence of $\mathrm{CuCl}$ and $\mathrm{K}_{2} \mathrm{CO}_{3}$ in $\mathrm{CH}_{2} \mathrm{Cl}_{2}$ for $3 \mathrm{~h}$, followed by removal of the solvent and the reaction with $\mathrm{TBAB}$ and $\mathrm{Na}_{2} \mathrm{~S}_{2} \mathrm{O}_{8}$ in a mixture of DCE and water at $90{ }^{\circ} \mathrm{C}$ for $19 \mathrm{~h}$ gave 3-bromo-4-phenylcoumarin (3Aa) in 52\% yield. For 3-aryl-2-propynoic acids bearing heteroaromatic groups, treatment of 3-(benzothiophen-2'-yl)-2-propynoic acid (1n) and 3-(benzofuran-2'-yl)-2-propynoic acid (10) under the same procedure and conditions gave the corresponding coumarins 3 An and $\mathbf{3 A o}$ in moderate yields, respectively. Under the present procedure and conditions, use of 2-hexynoic acid (1p), a 3-alkyl-2-propynoic acid, provided 3-bromo-4-propylcoumarin (3Ap) in $42 \%$ yield, as shown in Scheme 1.

Then, other diaryliodonium triflates were used instead of diphenyliodonium triflate (A). Treatment of 3-phenyl-2-propynoic acid (1a) with diaryliodonium triflates (1.0 equiv), such as $\operatorname{di}(p$-methylphenyl)iodonium triflate (B), di(tert-butylphenyl)iodonium triflate $(\mathbf{C}), \operatorname{di}(p$-chlorophenyl)iodonium triflate (D), and $\operatorname{di}(p$-bromophenyl)iodonium triflate $(\mathbf{E})$, in the presence of $\mathrm{CuCl}$ and $\mathrm{K}_{2} \mathrm{CO}_{3}$ in $\mathrm{CH}_{2} \mathrm{Cl}_{2}$ for $3 \mathrm{~h}$ under refluxing conditions, followed by removal of the solvent and the reaction with TBAB (2.0 equiv) and $\mathrm{Na}_{2} \mathrm{~S}_{2} \mathrm{O}_{8}$ (2.0 equiv) in a mixture of DCE and water at $90{ }^{\circ} \mathrm{C}$ for $19 \mathrm{~h}$ gave 3-bromo-4-phenylcoumarin derivatives $\mathbf{3 B a}-\mathbf{3 E a}$ bearing methyl, tert-butyl, chloro, and bromo groups at 7-position in good to moderate yields, respectively, as shown in Scheme 2.

As regards the synthetic utilization of the products in the present one-pot reaction, treatment of 3-bromo-4-phenylcoumarin (3Aa) with $\mathrm{Zn}$ in ethanol under refluxing conditions gave 4-phenylcoumarin (4Aa) in $81 \%$ yield. Treatment of 3-bromo-4-phenylcoumarin (3Aa) with $p$-toluenethiol/ $N, N$ 'dimethylethylenediamine (DMEDA) $/ \mathrm{K}_{2} \mathrm{CO}_{3}$ in the presence of $\mathrm{CuI}$ in toluene at refluxing temperature and with $p$-methoxybenzamide/DMEDA $/ \mathrm{K}_{2} \mathrm{CO}_{3}$ in the presence of $\mathrm{CuI}$ in toluene at refluxing temperature generated 3-(4-methylbenzenesulfenyl)4-phenylcoumarin (5Aa) and 3-(4-methoxylbenzoylamino)-4phenylcoumarin (6Aa) in 62 and $51 \%$ yields, respectively. The Pd-catalyzed coupling reactions of 3-bromo-4-phenylcoumarin (3Aa) with 4-methylstyrene $/ \mathrm{K}_{2} \mathrm{CO}_{3} / \mathrm{PdCl}_{2}\left(\mathrm{Ph}_{3} \mathrm{P}\right)_{2}$, with phenylacetylene $/ \mathrm{PdCl}_{2}\left(\mathrm{Ph}_{3} \mathrm{P}\right)_{2} / \mathrm{Et}_{3} \mathrm{~N}$ and with $\mathrm{PhB}(\mathrm{OH})_{2} / \mathrm{K}_{2} \mathrm{CO}_{3} /$ $\mathrm{PdCl}_{2}\left(\mathrm{Ph}_{3} \mathrm{P}\right)_{2}$ provided the corresponding $\mathrm{C}-\mathrm{C}$ bonded coumarin derivatives 7Aa, 8Aa, and 9Aa in 79, 60 and $76 \%$ yields, respectively (Scheme 3 ).

To support the present bromocyclization reaction to form 4-aryl-3-bromocoumarins with TBAB and $\mathrm{Na}_{2} \mathrm{~S}_{2} \mathrm{O}_{8}$ at the second step, the present one-pot preparation of 3-bromo-4phenylcoumarin (3Aa) from 3-phenyl-2-propynoic acid (1a) was carried out in the presence of 2,2,6,6-tetramethylpiperidine 1-oxyl radical (TEMPO, 2.0 equiv) or 2,6-di(tert-butyl- $p$-cresol (BHT, 3.0 equiv) at the second step under the same procedure and conditions, but 3-bromo-4-phenylcoumarin (3Aa) was not obtained at all in both reactions. Thus, the present bromocyclization of the formed phenyl 3-phenyl-2-propynoate (2Aa) 


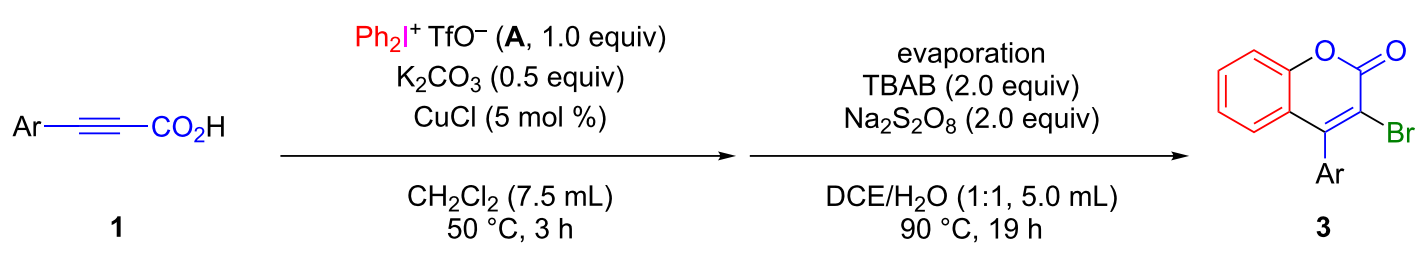

product, yield<smiles>O=c1oc2ccccc2c(Br)c1-c1ccccc1</smiles>

3Aa (54\%)

$(52 \%)^{a}$<smiles>COc1ccc(-c2c(Br)c(=O)oc3ccccc23)cc1</smiles>

3Ae $(52 \%)$<smiles>O=c1oc2ccccc2c(-c2cccc(Cl)c2)c1Br</smiles>

$3 \mathrm{Ai}(57 \%)$<smiles>O=c1oc2ccccc2c(-c2cccc3ccccc23)c1Br</smiles>

3Am (56\%)<smiles>Cc1ccccc1-c1c(Br)c(=O)oc2ccccc12</smiles>

$3 \mathrm{Ab}(57 \%)$<smiles>O=c1oc2ccccc2c(-c2ccc(F)cc2)c1Br</smiles>

3Af $(52 \%)$<smiles>O=c1oc2ccccc2c(-c2ccc(Br)cc2)c1Br</smiles>

3Aj (51\%)<smiles>O=c1oc2ccccc2c(-c2cc3ccccc3s2)c1Br</smiles>

3An $(46 \%)$<smiles>Cc1cccc(-c2c(Br)c(=O)oc3ccccc23)c1</smiles>

3Ac $(54 \%)$<smiles>O=c1oc2ccccc2c(-c2ccc(Cl)cc2)c1Br</smiles>

$3 \mathrm{Ag}(50 \%)$<smiles>O=c1oc2ccccc2c(-c2ccc(-c3ccccc3)cc2)c1Br</smiles>

3Ak (57\%)<smiles>O=c1oc2ccccc2c(-c2cc3ccccc3o2)c1Br</smiles>

3Ao (43\%)<smiles>Cc1ccc(-c2c(Br)c(=O)oc3ccccc23)cc1</smiles>

3Ad (58\%)<smiles>O=c1oc2ccccc2c(-c2ccccc2Cl)c1Br</smiles>

3Ah (64\%)<smiles>O=c1oc2ccccc2c(-c2ccc3ccccc3c2)c1Br</smiles>

3Al $(50 \%)$ 


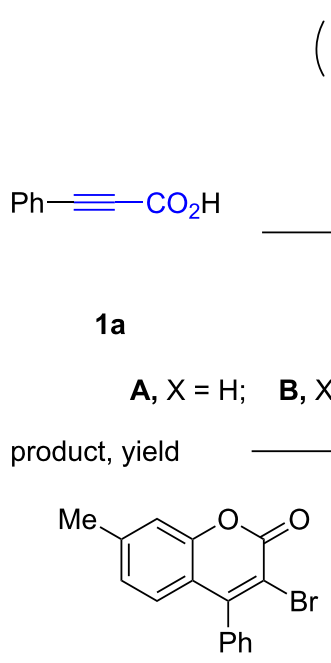

3Ba $(60 \%)$
$t-\mathrm{Bu}$<smiles>Cc1ccc2c(-c3ccccc3)c(Br)c(=O)oc2c1</smiles>

$3 \mathrm{Ca}(70 \%)$

evaporation;
$\underset{\mathrm{TBAB}(2.0 \text { equiv })}{\mathrm{Na}_{2} \mathrm{~S}_{2} \mathrm{O}_{8}(2.0 \text { equiv })}$
$\underset{\mathrm{DCE} / \mathrm{H}_{2} \mathrm{O}(1: 1,5.0 \mathrm{~mL})}{90^{\circ} \mathrm{C}, 19 \mathrm{~h}}$

$90{ }^{\circ} \mathrm{C}, 19 \mathrm{~h}$

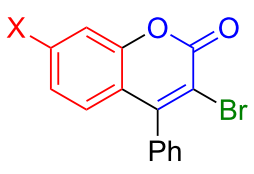

$3 a$
;
$\mathrm{C}, \mathrm{X}=t-\mathrm{Bu}$;
D, $\mathrm{X}=\mathrm{Cl}$;
$\mathrm{E}, \mathrm{X}=\mathrm{Br}$

Scheme 2: One-pot preparation of 3-bromo-4-phenylcoumarins 3a from 3-phenyl-2-propynoic acid (1a) with daryliodonium triflates B-E.<smiles>O=c1cc(-c2ccccc2)c2ccccc2o1</smiles>

\section{$\longleftarrow \frac{\mathrm{Zn}}{\mathrm{EtOH}, \text { reflux }}$}

$(81 \%)$

4Aa<smiles>Cc1ccc(Sc2c(-c3ccccc3)c3ccccc3oc2=O)cc1</smiles>

5Aa<smiles>COc1ccc(C(=O)Nc2c(-c3ccccc3)c3ccccc3oc2=O)cc1</smiles>

p-methoxybenzamide

$p$-toluenethiol

DMEDA

$\mathrm{K}_{2} \mathrm{CO}_{3}$, Cul

toluene, reflux

$(62 \%)$

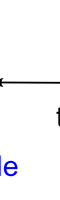

\section{DMEDA} $\mathrm{K}_{2} \mathrm{CO}_{3}$, Cul

toluene, reflux

$(51 \%)$
6Aa<smiles>O=c1oc2cc(Cl)ccc2c(-c2ccccc2)c1Br</smiles>

3Da (46\%)<smiles>O=c1oc2cc(Br)ccc2c(-c2ccccc2)c1Br</smiles>

3Ea (42\%)<smiles>CCc1cccc2c(-c3ccccc3)c(Br)c(=O)oc12</smiles>

3Aa

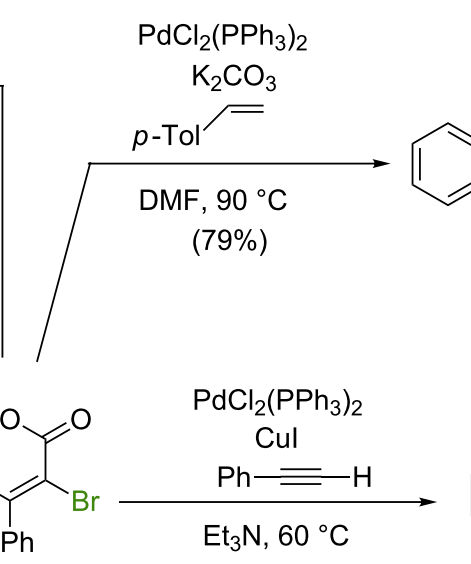

$(60 \%)$

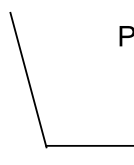

$\mathrm{PdCl}_{2}\left(\mathrm{PPh}_{3}\right)_{2}$

$\mathrm{PhB}(\mathrm{OH})_{2}$

$\mathrm{K}_{2} \mathrm{CO}_{3}$

DMF, $\mathrm{H}_{2} \mathrm{O}$

$60{ }^{\circ} \mathrm{C}$

(76\%)<smiles>Cc1ccc(/C=C/c2c(-c3ccccc3)c3ccccc3oc2=O)cc1</smiles>

$7 \mathrm{Aa}$<smiles>O=c1oc2ccccc2c(-c2ccccc2)c1C#Cc1ccccc1</smiles>

8Aa<smiles>O=c1oc2ccccc2c(-c2ccccc2)c1-c1ccccc1</smiles>

9Aa

Scheme 3: Derivatization of 3-bromo-4-phenylcoumarin.

with TBAB and $\mathrm{Na}_{2} \mathrm{~S}_{2} \mathrm{O}_{8}$ in a mixture of DCE and water is a radical-mediated bromocyclization reaction. X-ray crystallographic analysis of 3-bromo-7-chloro-4-phenylcoumarin (3Da), which was formed by the subsequent treatment of 3-phenyl-2- propynoic acid (1a) with di( $p$-chlorophenyl)iodonium triflate (D) and then with TBAB and $\mathrm{Na}_{2} \mathrm{~S}_{2} \mathrm{O}_{8}$, was carried out, as shown in Figure 1. Based on those results, the possible reaction pathway is shown in Scheme 4. 


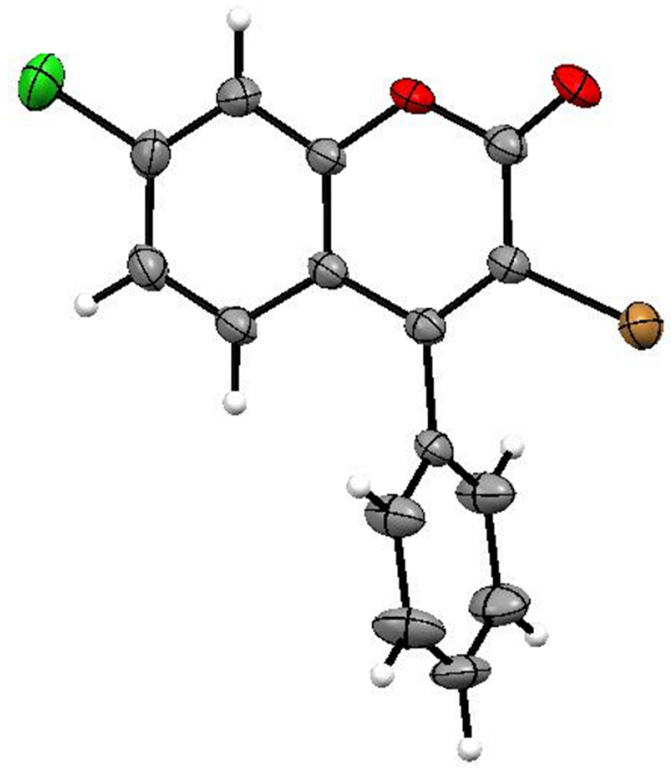

Figure 1: ORTEP of 3-bromo-7-chloro-4-phenylcoumarin (3Da).

The O-arylation of 3-aryl-2-propynoic acid $\mathbf{1}$ with diaryliodonium triflate in the presence of $\mathrm{K}_{2} \mathrm{CO}_{3}$ and $\mathrm{CuCl}$ occurs to form aryl 3-aryl-2-propynoate 2 (1st step). The bromocyclization of aryl 3-aryl-2-propynoate 2 with TBAB and $\mathrm{Na}_{2} \mathrm{~S}_{2} \mathrm{O}_{8}$ proceeds via a bromoradical addition to the triple bond to form very reac- tive vinyl radical I [47]. Ipso-cyclization of the vinyl radical I occurs to form spiro radical intermediate II. Then, $\beta$-cleavage of the spiro radical intermediate II proceeds to form carboxyl radical III. 6-Exo-trig cyclization of the carboxyl radical III onto the aromatic ring takes place to form adduct radical IV, which would be rapidly oxidized by $\mathrm{Na}_{2} \mathrm{~S}_{2} \mathrm{O}_{8}$ to form cation intermediate $\mathbf{V}$. Smooth deprotonation of cation intermediate $\mathbf{V}$ occurs to generate 4-aryl-3-bromocoumarin 3 (2nd step). The radical ipso-cyclization of the formed vinyl radical and its 1,2carboxyl group migration agree with previously reported results [31-34].

\section{Conclusion}

The successive treatment of 3-aryl-2-propynoic acids with diaryliodonium triflates in the presence of $\mathrm{K}_{2} \mathrm{CO}_{3}$ and $\mathrm{CuCl}$, and then with tetrabutylammonium bromide (TBAB) and $\mathrm{Na}_{2} \mathrm{~S}_{2} \mathrm{O}_{8}$ gave 4-aryl-3-bromocoumarins bearing hydrogen, methyl, tert-butyl, chloro, and bromo groups at 7-position in moderate yields, respectively. In one of the obtained 4-aryl-3bromocoumarins, the $\mathrm{C}-\mathrm{Br}$ bond of 3-bromo-4-phenylcoumarin was smoothly converted into 4-phenylcoumarins bearing $\mathrm{C}-\mathrm{H}, \mathrm{C}-\mathrm{S}, \mathrm{C}-\mathrm{N}$, and $\mathrm{C}-\mathrm{C}$ bonds at 3-position. We believe the present method will be useful for the preparation of various 4-arylcoumarin derivatives due to its simple one-pot synthesis.

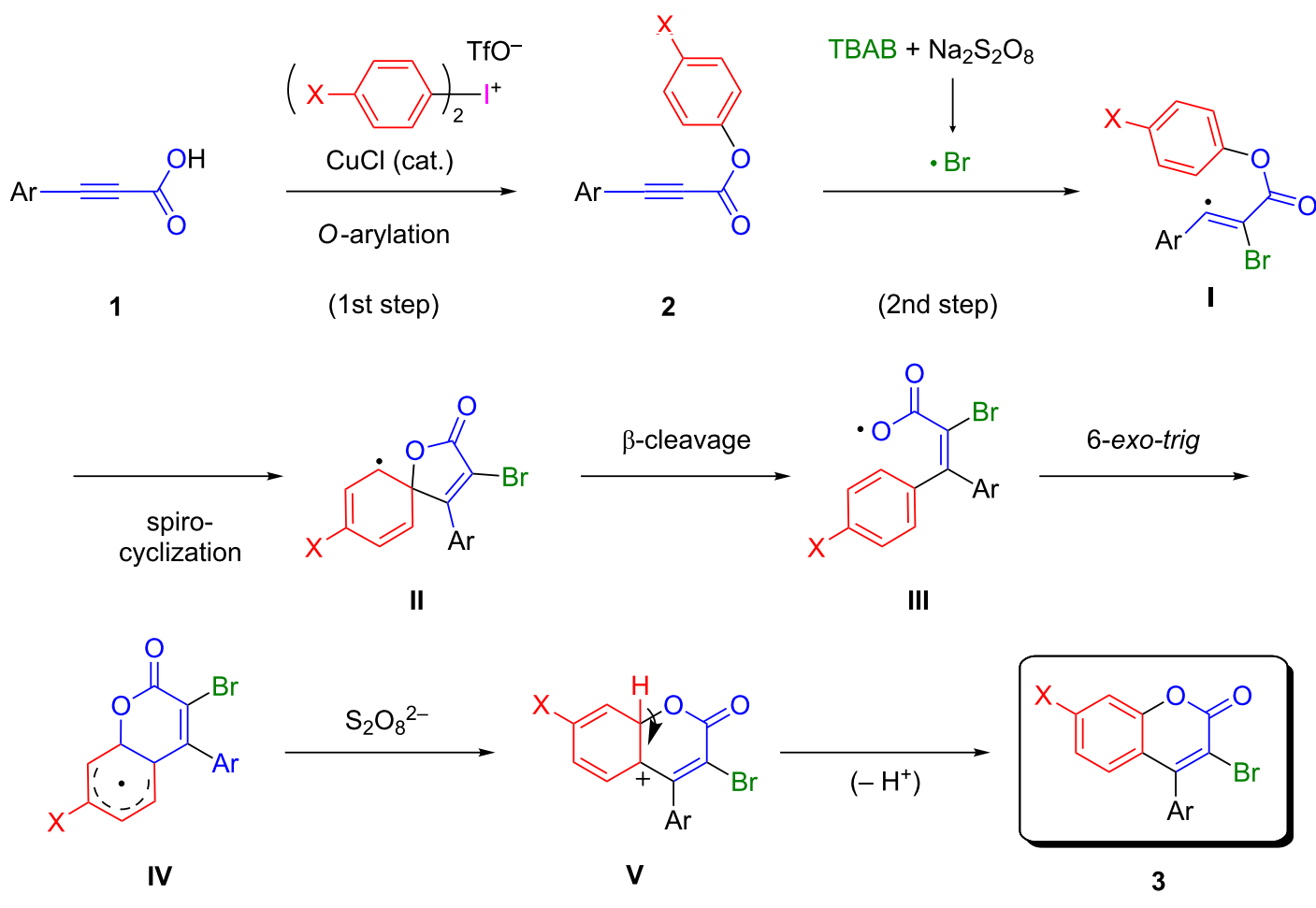




\section{Supporting Information}

\section{Supporting Information File 1}

NMR charts of all coumarin derivatives $\mathbf{3 A a}-\mathbf{3 A p}$,

3Ba-3Ea, and 4Aa-9Aa, and X-ray analytical data of 3Da. [https://www.beilstein-journals.org/bjoc/content/ supplementary/1860-5397-14-22-S1.pdf]

\section{Acknowledgements}

Financial support in the form of a Grant-in-Aid for Scientific Research (No. 15K05418) from the Ministry of Education, Culture, Sports, Science, and Technology in Japan is gratefully acknowledged.

\section{ORCID ${ }^{\circledR}$ iDs}

Hideo Togo - https://orcid.org/0000-0002-3633-7292

\section{References}

1. Lacy, A. Curr. Pharm. Des. 2004, 10, 3797-3811. doi:10.2174/1381612043382693

2. Musa, M. A.; Badisa, V. L. D.; Latinwo, L. M.; Waryoba, C.; Ugochukwu, N. Anticancer Res. 2010, 30, 4613-4617.

3. Medina, F. G.; Marrero, J. G.; Macías-Alonso, M.; González, M. C.; Córdova-Guerrero, I.; García, A. G. T.; Osegueda-Robles, S. Nat. Prod. Rep. 2015, 32, 1472-1507. doi:10.1039/C4NP00162A

4. Sashidhara, K. V.; Kumar, A.; Chatterjee, M.; Rao, K. B.; Singh, S.; Verma, A. K.; Palit, G. Bioorg. Med. Chem. Lett. 2011, 21, 1937-1941. doi:10.1016/j.bmcl.2011.02.040

5. Ostrov, D. A.; Hernández-Prada, J. A.; Corsino, P. E.; Finton, K. A.; Le, N.; Rowe, T. C. Antimicrob. Agents Chemother. 2007, 51, 3688-3698. doi:10.1128/AAC.00392-07

6. Chimenti, F.; Bizzarri, B.; Bolasco, A.; Secci, D.; Chimenti, P.; Granese, A.; Carradori, S.; Rivanera, D.; Zicari, A.; Scaltrito, M. M.; Sisto, F. Bioorg. Med. Chem. Lett. 2010, 20, 4922-4926. doi:10.1016/j.bmcl.2010.06.048

7. Kostova, I.; Bhatia, S.; Grigorov, P.; Balkansky, S.; Parmar, V. S.; Prasad, A. K.; Saso, L. Curr. Med. Chem. 2011, 18, 3929-3951. doi:10.2174/092986711803414395

8. Xi, G.-L.; Liu, Z.-Q. J. Agric. Food Chem. 2015, 63, 3516-3523. doi:10.1021/acs.jafc.5b00399

9. Bansal, Y.; Sethi, P.; Bansal, G. Med. Chem. Res. 2013, 22, 3049-3060. doi:10.1007/s00044-012-0321-6

10. Fylaktakidou, K. C.; Hadjipavlou-Litina, D. J.; Litinas, K. E.; Nicolaides, D. N. Curr. Pharm. Des. 2004, 10, 3813-3833. doi: $10.2174 / 1381612043382710$

11. De Almeida Barros, T. A.; De Freitas, L. A. R.; Filho, J. M. B.; Nunes, X. P.; Giulietti, A. M.; De Souza, G. E.; Dos Santos, R. R.; Soares, M. B. P.; Villarreal, C. F. J. Pharm. Pharmacol. 2010, 62, 205-213. doi:10.1211/jpp.62.02.0008

12. Sánchez-Recillas, A.; Navarrete-Vázquez, G.; Hidalgo-Figueroa, S.; Rios, M. Y.; Ibarra-Barajas, M.; Estrada-Soto, S. Eur. J. Med. Chem. 2014, 77, 400-408. doi:10.1016/j.ejmech.2014.03.029

13. Hwu, J. R.; Lin, S.-Y.; Tsay, S.-C.; De Clercq, E.; Leyssen, P.; Neyts, J. J. Med. Chem. 2011, 54, 2114-2126. doi:10.1021/jm101337v
14. Ong, E. B. B.; Watanabe, N.; Saito, A.; Futamura, Y.; El Galil, K. H. A.; Koito, A.; Najimudin, N.; Osada, H. J. Biol. Chem. 2011, 286, 14049-14056. doi:10.1074/jbc.M110.185397

15. Vekariya, R. H.; Patel, H. D. Synth. Commun. 2014, 44, 2756-2788. doi:10.1080/00397911.2014.926374

16. Žalubovskis, R. Chem. Heterocycl. Compd. (Engl. Transl.) 2015, 51, 607-612. doi:10.1007/s10593-015-1748-8

17. Sethna, S.; Phadke, R. Org. React. 2011, 7, 1-58. doi:10.1002/0471264180.or007.01

18. Fiorito, S.; Epifano, F.; Taddeo, V. A.; Genovese, S. Tetrahedron Lett. 2016, 57, 2939-2942. doi:10.1016/j.tetlet.2016.05.087

19. Ferguson, J.; Zeng, F.; Alper, H. Org. Lett. 2012, 14, 5602-5605. doi:10.1021/ol302725x

20. Mantovani, A. C.; Goulart, T. A. C.; Back, D. F.; Menezes, P. H.; Zeni, G. J. Org. Chem. 2014, 79, 10526-10536. doi:10.1021/jo502199q

21. Zhao, Y.; Han, F.; Yang, L.; Xia, C. Org. Lett. 2015, 17, 1477-1480. doi:10.1021/acs.orglett.5b00364

22. Choi, H.; Kim, J.; Lee, K. Tetrahedron Lett. 2016, 57, 3600-3603. doi:10.1016/j.tetlet.2016.06.039

23. Metternich, J. B.; Gilmour, R. J. Am. Chem. Soc. 2016, 138, 1040-1045. doi:10.1021/jacs.5b12081

24. Yan, K.; Yang, D.; Wei, W.; Wang, F.; Shuai, Y.; Li, Q.; Wang, H. J. Org. Chem. 2015, 80, 1550-1556. doi:10.1021/jo502474z

25. Li, Y.; Lu, Y.; Qiu, G.; Ding, Q. Org. Lett. 2014, 16, 4240-4243. doi:10.1021/ol501939m

26. Mi, X.; Wang, C.; Huang, M.; Zhang, J.; Wu, Y.; Wu, Y. Org. Lett. 2014, 16, 3356-3359. doi:10.1021/ol5013839

27. Fu, W.; Zhu, M.; Zou, G.; Xu, C.; Wang, Z.; Ji, B. J. Org. Chem. 2015, 80, 4766-4770. doi:10.1021/acs.joc.5b00305

28. Mi, X.; Wang, C.; Huang, M.; Wu, Y.; Wu, Y. J. Org. Chem. 2015, 80, 148-155. doi:10.1021/jo502220b

29. Yang, W.; Yang, S.; Li, P.; Wang, L. Chem. Commun. 2015, 51, 7520-7523. doi:10.1039/C5CC00878F

30. Wei, W.; Wen, J.; Yang, D.; Guo, M.; Wang, Y.; You, J.; Wang, H. Chem. Commun. 2015, 51, 768-771. doi:10.1039/C4CC08117J

31. Qiu, G.; Liu, T.; Ding, Q. Org. Chem. Front. 2016, 3, 510-515. doi:10.1039/C6Q000041J

32. Yu, Y.; Zhuang, S.; Liu, P.; Sun, P. J. Org. Chem. 2016, 81, 11489-11495. doi:10.1021/acs.joc.6b02155

33. Ni, S.; Cao, J.; Mei, H.; Han, J.; Li, S.; Pan, Y. Green Chem. 2016, 18, 3935-3939. doi:10.1039/C6GC01027J

34. Feng, S.; Li, J.; Li, Z.; Sun, H.; Shi, H.; Wang, X.; Xie, X.; She, X. Org. Biomol. Chem. 2017, 15, 8820-8826. doi:10.1039/C7OB02199B

35. Aradi, K.; Tóth, B. L.; Tolnai, G. L.; Novák, Z. Synlett 2016, 27, 1456-1485. doi:10.1055/s-0035-1561369

36. Olofsson, B. Top. Curr. Chem. 2015, 373, 135-166. doi:10.1007/128_2015_661

37. Fañanás-Mastral, M. Synthesis 2017, 49, 1905-1930. doi:10.1055/s-0036-1589483

38. Stuart, D. R. Chem. - Eur. J. 2017, 23, 15852-15863. doi:10.1002/chem.201702732

39. Cao, C. K.; Sheng, J.; Chen, C. Synthesis 2017, 49, 5081-5092. doi:10.1055/s-0036-1589515

40. Petersen, T. B.; Khan, R.; Olofsson, B. Org. Lett. 2011, 13, 3462-3465. doi:10.1021/ol2012082

41. Jalalian, N.; Petersen, T. B.; Olofsson, B. Chem. - Eur. J. 2012, 18, 14140-14149. doi:10.1002/chem.201201645 
42. Mutai, P.; Breuzard, G.; Pagano, A.; Allegro, D.; Peyrot, V.; Chibale, K. Bioorg. Med. Chem. 2017, 25, 1652-1665.

doi:10.1016/j.bmc.2017.01.035

43. Kakinuma, Y.; Moriyama, K.; Togo, H. Synthesis 2013, 45, 183-188. doi:10.1055/s-0032-1316824

44. Miyagi, K.; Moriyama, K.; Togo, H. Heterocycles 2014, 89, 2122-2136. doi:10.3987/COM-14-13071

45. Sasaki, T.; Miyagi, K.; Moriyama, K.; Togo, H. Org. Lett. 2016, 18, 944-947. doi:10.1021/acs.orglett.5b03651

46. Sasaki, T.; Moriyama, K.; Togo, H. J. Org. Chem. 2017, 82, 11727-11734. doi:10.1021/acs.joc.7b01433

47. Togo, H. Advanced Free Radicals for Organic Synthesis; Chapter 3; Elsevier: Oxford, 2004; pp 75-94.

\section{License and Terms}

This is an Open Access article under the terms of the Creative Commons Attribution License

(http://creativecommons.org/licenses/by/4.0), which permits unrestricted use, distribution, and reproduction in any medium, provided the original work is properly cited.

The license is subject to the Beilstein Journal of Organic Chemistry terms and conditions:

(https://www.beilstein-journals.org/bjoc)

The definitive version of this article is the electronic one which can be found at: doi:10.3762/bjoc. 14.22 